\title{
Significance of INHBA expression in human colorectal cancer
}

\author{
MIHO OKANO ${ }^{1}$, HIROFUMI YAMAMOTO ${ }^{1}$, HISATAKA OHKUMA ${ }^{1,3}$, YOSHIHIRO KANO ${ }^{1,2}$, HIROTOSHI KIM ${ }^{1}$, \\ SHIMPEI NISHIKAWA ${ }^{1,2}$, MASAMITSU KONNO ${ }^{2}$, KOICHI KAWAMOTO ${ }^{1}$, NAOTSUGU HARAGUCHI ${ }^{2}$, \\ ICHIRO TAKEMASA ${ }^{1}$, TSUNEKAZU MIZUSHIMA ${ }^{1}$, MASATAKA IKEDA ${ }^{1}$, TAKEHIKO YOKOBORI ${ }^{3}$, \\ KOSHI MIMORI ${ }^{3}$, MITSUGU SEKIMOTO ${ }^{1}$, YUICHIRO DOKI ${ }^{1}$, MASAKI MORI ${ }^{1}$ and HIDESHI ISHII ${ }^{2}$ \\ Departments of ${ }^{1}$ Gastroenterological Surgery and ${ }^{2}$ Frontier Science for Cancer and Chemotherapy, \\ Graduate School of Medicine, Osaka University, Suita, Osaka 565-0871; ${ }^{3}$ Department of Surgery, \\ Kyushu University Beppu Hospital, Oita 874-0838, Japan
}

Received June 12, 2013; Accepted August 6, 2013

DOI: 10.3892/or.2013.2761

\begin{abstract}
Inhibin $\beta \mathrm{A}(I N H B A)$ is a member of the transforming growth factor $\beta$ (TGF- $\beta$ ) superfamily. INHBA expression is associated with several types of human cancers; however, its significance in colorectal cancer (CRC) is not fully understood. INHBA expression was studied in 126 primary CRC samples and $4 \mathrm{CRC}$ cell lines. Cell growth was assessed after inhibition of INHBA expression or after exogenous overexpression of INHBA in CRC tissues. INHBA expression was significantly higher in $\mathrm{CRC}$ tissues when compared to that in the corresponding normal tissues $(\mathrm{P}<0.001)$. Patients in the high expression group showed a poorer overall survival rate when compared to those in the low expression group $(\mathrm{P}<0.001)$; the present study did not evaluate for an independent prognostic factor but showed the significance of lymph node metastasis as an independent prognostic factor. The present study suggests that INHBA is useful as a predictive marker for prognosis in CRC patients.
\end{abstract}

\section{Introduction}

In many developed countries, cancer is one of the most common causes of death. The incidence of colorectal cancer (CRC) has recently increased in Japan, in concert with changing lifestyles (1). The major cause of death from cancer is distant metastases. Identification of genes responsible for

Correspondence to: Dr Hirofumi Yamamoto, Department of Gastroenterological Surgery, Graduate School of Medicine, Osaka University, Yamada-oka 2-2, Suita, Osaka 565-0871, Japan

E-mail: hyamamoto@gesurg.med.osaka-u.ac.jp

Dr Hideshi Ishii, Department of Frontier Science for Cancer and Chemotherapy, Graduate School of Medicine, Osaka University, Yamada-oka 2-2, Suita, Osaka 565-0871, Japan

E-mail: hishii@gesurg.med.osaka-u.ac.jp

Key words: inhibin $\beta$ A, prognosis, colorectal cancer development and progression of CRC and understanding their clinical significance are critical for the establishment of adequate treatments for this disease $(2,3)$.

Inhibin $\beta \mathrm{A}(I N H B A)$ is a member of the transforming growth factor $\beta$ (TGF- $\beta$ ) superfamily (4). INHBA forms a disulfide-linked homodimer known as activin $\mathrm{A}$, which was originally described in 1978 for its role in the hypothalamicpituitary-gonadal axis $(5,6)$. It is able to strongly induce embryonic stem cell differentiation (7). Its expression is increased in carcinoma tissues, as established by studies of activin A levels in esophageal (8), pancreatic (9), prostate (10), and ovarian $(11,12)$ cancers, and patients with endometrial and cervical carcinomas have high serum levels of activin A (13).

The aim of this study was to analyze the correlation between INHBA expression in CRC tissues obtained from patients and clinicopathological factors. In addition, we performed an in vitro study in which gene knockdown techniques and the introduction of INHBA were used to investigate the relevance of $I N H B A$ expression and its relationship with clinicopathological characteristics.

\section{Materials and methods}

Cell culture. Human CRC cell lines (CaR1, CCK81 and DLD-1) were obtained and cultured in minimum essential medium (MEM; Invitrogen Life Technologies, Carlsbad, CA, USA) containing $10 \%$ fetal bovine serum (FBS; Gibco-BRL, Carlsbad, CA, USA) and antibiotics at $37^{\circ} \mathrm{C}$ in a humidified atmosphere containing $5 \% \mathrm{CO}_{2}$. Caco-2 cells were cultured in MEM containing 20\% FBS. For the small interference RNA (siRNA) knockdown experiment, RNA duplexes that targeted human INHBA (5' end) were synthesized (Hs_INHBA_4HPsiRNA; Qiagen, Valencia, CA, USA). AllStars Neg siRNA was used as a negative control (sense sequence, UUCUCCGAACGUGUCACGU; Qiagen). CRC cell lines were transfected with $15 \mu \mathrm{mol} / \mathrm{l}$ siRNA using HiPerFect transfection reagent (Qiagen). The growth rate of the cell culture was measured by counting cells using a CellTac kit (Nihon Koden, Tokyo, Japan). Triple transfection was performed using all the siRNA duplexes together. Plasmids containing human INHBA NM_002192 (OriGene Inc., 
Rockville, MA, USA) were transfected into CCK81, DLD-1 and Caco-2 cells using Lipofectamine ${ }^{\mathrm{TM}} 2000$ (Invitrogen Life Technologies). An empty vector was used as a mock control. Values are presented as means \pm standard deviation (SD) of 3 independent experiments.

Clinical tissue samples. From 1992 to 2002, 126 patients (75 men and 51 women) diagnosed with CRC underwent surgical resection at the Medical Institute of Bioregulation at Kyushu University. Primary CRC specimens and their adjacent normal colorectal mucosa were obtained from patients after obtaining their informed consent and in accordance with the institutional guidelines. Each patient was definitively diagnosed as having CRC on the basis of clinicopathological findings. The resected surgical specimens were equally divided into two halves; one half was frozen in liquid nitrogen and preserved at $-80^{\circ} \mathrm{C}$ for RNA study, and the other half was fixed in formalin, processed through graded ethanol, and embedded in paraffin. The formalin-fixed sections were stained with hematoxylin and eosin and elastic van Gieson, and the degree of histological differentiation, lymphatic invasion, and venous invasion was microscopically examined. None of the patients received chemotherapy or radiotherapy before surgery. Clinicopathological factors were assessed according to the tumor-node-metastasis (TNM) classification criteria as defined by the International Union Against Cancer $(14,15)$. The patients were followed up with blood examination, including for levels of tumor markers such as serum carcinoembryonic antigen and cancer antigen, and underwent imaging investigations such as abdominal ultrasonography and/or computer tomography as well as chest radiography every 3-6 months.

RNA study. Total RNA was extracted from the frozen tissues, and reverse transcription was performed $(16,17)$. Two human $I N H B A$ oligonucleotide primers used for PCR were designed as 238-bp INHBA fragments [5'-CCTCGGAGATCATCACG TTT-3' (forward) and 5'-CCCTTTAAGCCCACTTCCTC-3' (reverse)]. The forward primer was located in exon 1, and the reverse primer was located in exon 2. As an internal control, a PCR assay was performed using primers specific to glyceraldehyde-3-phosphate dehydrogenase $(G A P D H)$. These GAPDH primers, 5'-TTGGTATCGTGGAAGGACTCA-3' (forward) and 5'-TGTCATCATATTGGCAGGTT-3' (reverse), produced a 270-bp amplicon. Real-time PCR monitoring was performed using the LightCycler system (Roche Diagnostics, Tokyo, Japan) for complementary DNA (cDNA) amplification of INHBA and GAPDH. The amplification protocol consisted of 40 cycles of denaturation at $95^{\circ} \mathrm{C}$ for $10 \mathrm{sec}$, annealing at $60^{\circ} \mathrm{C}$ for $10 \mathrm{sec}$, and elongation at $72^{\circ} \mathrm{C}$ for $10 \mathrm{sec}$. The PCR products were then subjected to a temperature gradient from $55^{\circ} \mathrm{C}$ to $95^{\circ} \mathrm{C}$ at $0.1^{\circ} \mathrm{C} \mathrm{sec}-1$ with continuous fluorescence monitoring to produce product melting curves. The mRNA expression ratio of tumor to normal tissues was calculated and normalized against GAPDH mRNA expression.

Statistical analysis. For continuous variables used in an in vitro analysis, data are expressed as means $\pm \mathrm{SD}$ and were analyzed using the Wilcoxon rank test. The relationship between mRNA expression and clinicopathological factors was analyzed using the Chi-square and Student's t-tests.

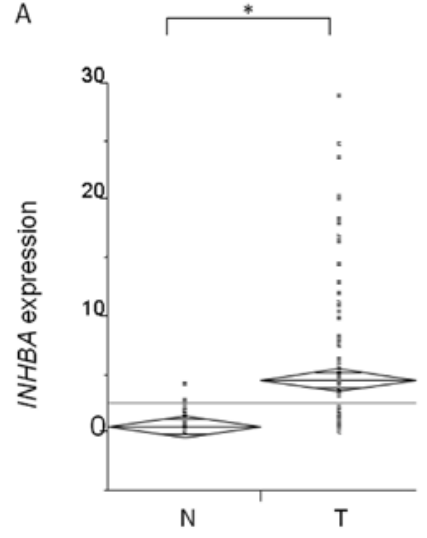

B

Figure 1. (A) INHBA mRNA expression in clinical tissue specimens. Quantitative RT-PCR of 126 clinical samples showed that $116(92.1 \%)$ of these samples had higher levels of INHBA mRNA compared with the matched normal tissues. Mean INHBA mRNA expression in tumor tissues (normalized against $G A P D H$ expression) was significantly higher than that of the corresponding normal tissues ( $\mathrm{P}<0.001$; Student's t-test). (B) Overall survival curves of CRC patients, based on the INHBA mRNA expression status. The overall survival rate was better in the low expression group than that in the high expression group $\left({ }^{*} \mathrm{P}=0.0016\right)$. INHBA, inhibin $\beta \mathrm{A} ; \mathrm{CRC}$, colorectal cancer.

Kaplan-Meier survival curves were plotted and compared using a generalized log-rank test. Univariate and multivariate analyses for the identification of factors prognostic for overall survival were performed using the Cox proportional hazard regression model. All tests were analyzed using JMP software (SAS Institute Inc., Cary, NC, USA). P-values of $<0.05$ were considered statistically significant.

\section{Results}

INHBA mRNA expression in CRC clinical tissue specimens and clinicopathological characteristics. We performed quantitative real-time RT-PCR analysis using primary CRC and adjacent noncancerous CRC tissues. RT-PCR of 126 paired clinical samples showed that $116(92.1 \%)$ of these samples exhibited higher INHBA mRNA levels in tumor tissues than in paired normal tissues (Fig. 1A). INHBA expression was calculated as INHBA/GAPDH expression. For the evaluation of clinicopathological factors, the tissue samples were divided into 2 groups according to $I N H B A$ expression. Patients with tumors that had a more than median INHBA expression were assigned to the high expression group $(n=63)$; the others were assigned to the low expression group $(n=63)$. Clinicopathological factors related to the INHBA expression status of the 126 patients are summarized in Table I. The data indicated that INHBA expression was correlated with the tumor stage $(\mathrm{P}<0.0001)$, lymph node metastasis $(\mathrm{P}<0.0001)$, lymphatic invasion $(\mathrm{P}=0.0013)$, venous invasion $(\mathrm{P}<0.0001)$ and liver metastasis $(\mathrm{P}=0.0024)$. Other factors were not significantly correlated with INHBA expression.

Relationship between INHBA expression and prognosis. The data showed that the overall survival rate was significantly lower in the high expression group than in the low expression group ( $\mathrm{P}=0.0016)$ (Fig. 1B). The median follow-up period was 
Table I. Clinicopathological factors and INHBA mRNA expression in $126 \mathrm{CRC}$ patients.

\begin{tabular}{|c|c|c|c|}
\hline \multirow[b]{2}{*}{ Factors } & \multicolumn{2}{|c|}{$\begin{array}{l}I N H B A / G A P D H \\
\text { expression }\end{array}$} & \multirow[b]{2}{*}{ P-value } \\
\hline & $\begin{array}{c}\text { High } \\
\mathrm{n}=63, \mathrm{n}(\%)\end{array}$ & $\begin{array}{c}\text { Low } \\
\mathrm{n}=63, \mathrm{n}(\%)\end{array}$ & \\
\hline \multicolumn{4}{|l|}{ Age (years) } \\
\hline$\leq 68$ & $31(49.2)$ & $30(47.6)$ & 0.87 \\
\hline$>68$ & $32(50.8)$ & $33(52.6)$ & \\
\hline \multicolumn{4}{|l|}{ Gender } \\
\hline Male & $41(65.1)$ & $35(55.6)$ & 0.26 \\
\hline Female & $22(34.9)$ & $28(44.4)$ & \\
\hline \multicolumn{4}{|c|}{ Histological grade } \\
\hline Well, mod & $58(92.1)$ & $61(96.8)$ & 0.22 \\
\hline Others & $5 \quad(7.9)$ & $2(3.2)$ & \\
\hline \multicolumn{4}{|c|}{ Tumor stage } \\
\hline T0-T2 & $6 \quad(9.5)$ & $29(46.0)$ & $<0.0001^{\mathrm{a}}$ \\
\hline T3-T4 & $57(90.5)$ & $34(54.0)$ & \\
\hline \multicolumn{4}{|c|}{ Lymph node metastasis } \\
\hline Absent & $21(33.3)$ & $47(74.6)$ & $<0.0001^{\mathrm{a}}$ \\
\hline Present & $42(66.7)$ & $16(25.4)$ & \\
\hline \multicolumn{4}{|c|}{ Lymphatic invasion } \\
\hline Absent & $37(58.7)$ & $44(69.8)$ & $0.0013^{\mathrm{a}}$ \\
\hline Present & $26(41.3)$ & $19(30.2)$ & \\
\hline \multicolumn{4}{|c|}{ Venous invasion } \\
\hline Absent & $43(68.3)$ & $60(95.2)$ & $<0.0001^{\mathrm{a}}$ \\
\hline Present & $20(31.7)$ & $3(4.8)$ & \\
\hline \multicolumn{4}{|c|}{ Liver metastasis } \\
\hline Absent & $49(77.8)$ & $60(95.2)$ & $0.0024^{\mathrm{a}}$ \\
\hline Present & $14(22.2)$ & $3(4.8)$ & \\
\hline \multicolumn{4}{|c|}{$\begin{array}{l}\text { Peritoneal } \\
\text { dissemination }\end{array}$} \\
\hline Absent & $59(93.7)$ & $62(98.4)$ & 0.15 \\
\hline Present & $4 \quad(6.3)$ & 1 (1.6) & \\
\hline
\end{tabular}

a $\mathrm{P}<0.01$. CRC, colorectal cancer; INHBA, inhibin $\beta \mathrm{A} ; G A P D H$, glyceraldehyde-3-phosphate dehydrogenase; well, well-differentiated adenocarcinoma; mod, moderately differentiated adenocarcinoma; others, poorly differentiated adenocarcinoma and signet cell carcinoma.

$3.33 \pm 2.67$ years. Table II shows the results of the univariate and multivariate analyses of factors related to overall survival. Univariate analysis showed that the following factors were significantly related to overall survival: histological grade ( $\mathrm{P}=0.0139)$, tumor stage $(\mathrm{P}=0.0006)$, lymph node metastasis $(\mathrm{P}<0.0001)$, lymphatic invasion $(\mathrm{P}<0.0001)$, venous invasion $(\mathrm{P}=0.0011)$, liver metastasis $(\mathrm{P}<0.0001)$ and $I N H B A \mathrm{mRNA}$ expression $(\mathrm{P}=0.0007)$. Multivariate analysis indicated that lymphatic invasion and liver metastasis were independent predictors of overall survival. INHBA mRNA high expression was not an independent predictor.
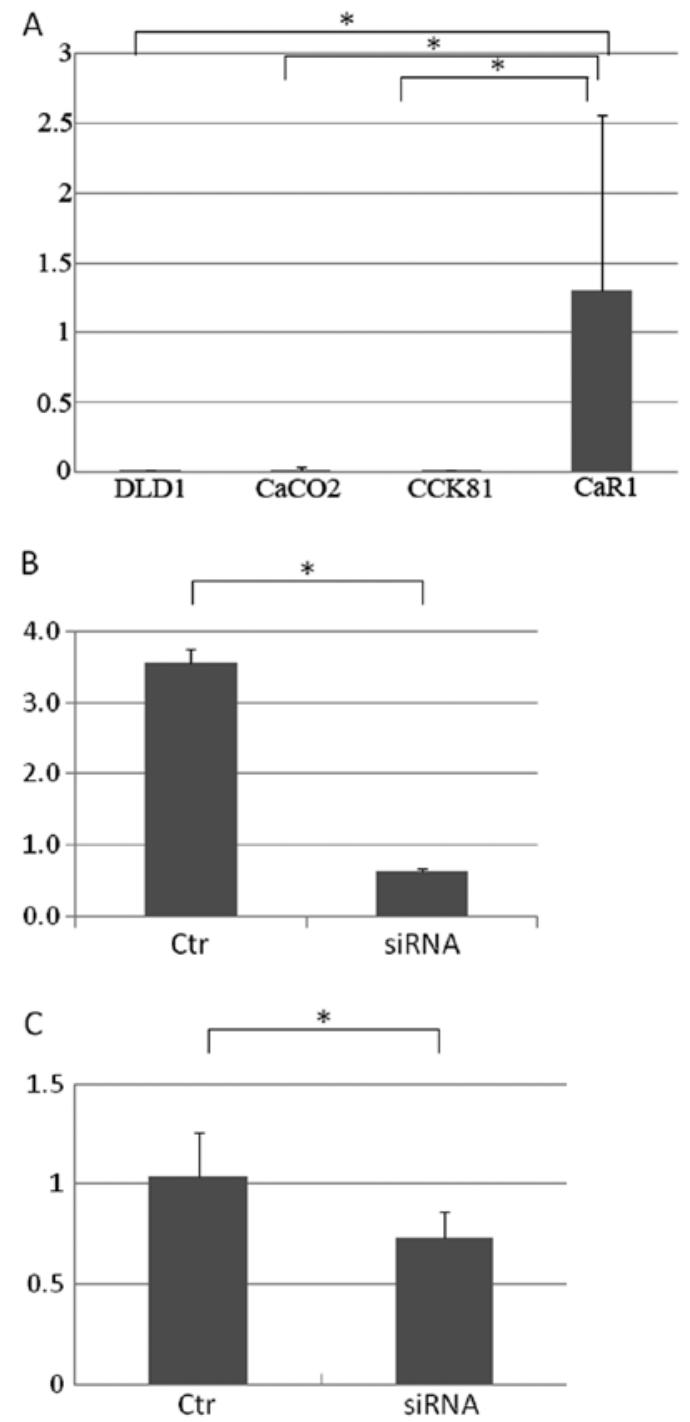

Figure 2. (A) INHBA mRNA expression in 4 CRC cell lines. INHBA expression status was evaluated using 4 cell lines derived from human CRC (DLD1, Caco-2, CCK81 and CaR1) using quantitative real-time RT-PCR analysis. $\mathrm{CaR} 1$ had significantly higher $I N H B A \mathrm{mRNA}$ expression than the other cell lines. (B) Knockdown assessment of $I N H B A$ by siRNA in the CaR1 cell line. Quantitative real-time RT-PCR confirmed reduced INHBA mRNA levels $\left({ }^{*} \mathrm{P}<0.05\right)$. (C) A proliferation assay was performed using the CaR1 cell line. Significant differences were observed between NC and INHBA siRNA $\left(\mathrm{n}=3,{ }^{*} \mathrm{P}<0.05\right)$. An in vitro assay showed differences in the ratio when compared to the control (with no treatment) cells. Values are presented as means and SEM. INHBA, inhibin $\beta$ A; CRC, colorectal cancer; NC, negative control.

Relationship between INHBA expression and lymph node metastasis. Table III shows the univariate and multivariate analyses of factors affecting lymph node metastasis. Univariate analysis showed that the following factors were significantly related to lymph node metastasis: histological grade $(\mathrm{P}=0.0341)$, tumor stage $(\mathrm{P}=0.0028)$, lymphatic invasion $(\mathrm{P}=0.0215)$ and $I N H B A$ mRNA high expression $(\mathrm{P}=0.0074)$. Multivariate analysis indicated that inclusion in the INHBA mRNA high expression group [relative risk (RR), 3.95; 95\% confidence interval (CI), 1.71-9.35; $\mathrm{P}=0.0014]$ was an independent predictor of lymph node metastasis, as was lymphatic invasion (RR, 3.25; 95\% CI, 1.39-7.72; $\mathrm{P}=0.0067$ ). 
Table II. Univariate and multivariate analysis of the clinicopathological factors affecting survival rate.

\begin{tabular}{|c|c|c|c|c|c|}
\hline \multirow[b]{2}{*}{ Factors } & \multirow[b]{2}{*}{ No. of patients } & \multicolumn{2}{|c|}{ Univariate analysis } & \multicolumn{2}{|c|}{ Multivariate analysis } \\
\hline & & 5 -year survival rate $(\%)$ & P-value & Relative risk $(95 \% \mathrm{CI})$ & P-value \\
\hline \multicolumn{6}{|l|}{ Age (years) } \\
\hline$\leq 68$ & 60 & 76.5 & 0.180 & & \\
\hline$>68$ & 66 & 61.8 & & & \\
\hline \multicolumn{6}{|l|}{ Gender } \\
\hline Male & 75 & 67.4 & 0.389 & & \\
\hline Female & 51 & 73.1 & & & \\
\hline \multicolumn{6}{|c|}{ Histological grade } \\
\hline Well, mod & 119 & 71.8 & $0.0139^{\mathrm{a}}$ & $1.75(0.81-3.25)$ & 0.139 \\
\hline Others & 7 & 33.3 & & & \\
\hline \multicolumn{6}{|l|}{ Tumor stage } \\
\hline T0-T2 & 36 & 93.1 & $0.0006^{\mathrm{b}}$ & $1.26(0.60-3.34)$ & 0.566 \\
\hline $\mathrm{T} 3-\mathrm{T} 4$ & 90 & 58.9 & & & \\
\hline \multicolumn{6}{|c|}{ Lymph node metastasis } \\
\hline Absent & 69 & 85.9 & $<0.0001^{\mathrm{b}}$ & $1.20(0.75-2.03)$ & 0.461 \\
\hline Present & 57 & 50.0 & & & \\
\hline \multicolumn{6}{|c|}{ Lymphatic invasion } \\
\hline Absent & 71 & 84.1 & $<0.0001^{\mathrm{b}}$ & $2.23(1.40-3.73)$ & $0.0006^{\mathrm{b}}$ \\
\hline Present & 55 & 51.8 & & & \\
\hline \multicolumn{6}{|c|}{ Venous invasion } \\
\hline Absent & 103 & 77.5 & $0.0011^{\mathrm{b}}$ & $1.41(0.91-2.11)$ & 0.112 \\
\hline Present & 23 & 36.2 & & & \\
\hline \multicolumn{6}{|c|}{ Liver metastasis } \\
\hline Absent & 17 & 79.5 & $<0.0001^{\mathrm{b}}$ & $2.56(1.67-3.97)$ & $0.0000^{\mathrm{b}}$ \\
\hline Present & 109 & 20.3 & & & \\
\hline \multicolumn{6}{|c|}{ INHBA expression } \\
\hline High & 63 & 49.9 & $0.0007^{\mathrm{b}}$ & $1.16(0.73-1.92)$ & 0.546 \\
\hline Low & 63 & 86.5 & & & \\
\hline
\end{tabular}

${ }^{\mathrm{a}} \mathrm{p}<0.05 ;{ }^{\mathrm{b}} \mathrm{p}<0.01$. RR, relative risk; CI, confidence interval; well, well-differentiated adenocarcinoma; mod, moderately differentiated adenocarcinoma; others, poorly differentiated adenocarcinoma and signet cell carcinoma; INHBA, inhibin $\beta$ A.

In vitro assessment of knockdown and transfection of INHBA. The INHBA expression study indicated that CaR1 cells had higher levels of expression than other CRC cell lines such as DLD1, Caco-2 and CCK81 (Fig. 2A). We performed a knockdown experiment of INHBA expression using the CaR1 cell line. After 48 h of siRNA transfection, quantitative real-time RT-PCR was used to confirm the reduction in INHBA expression due to siRNA treatment (Fig. 2B). A proliferation assay indicated that the knockdown resulted in a reduction in the number of $\mathrm{CaR} 1$ cells at $72 \mathrm{~h}(\mathrm{P}<0.05$; Fig. 2C). We induced INHBA expression in the cell lines (DLD1, Caco-2 and CCK81) using a plasmid technique, and quantitative real-time RT-PCR confirmed successful induction in them (Fig. 3A-C). Proliferation assays indicated that high INHBA expression increased the cell numbers of CRC cells, which have low INHBA expression by default $(\mathrm{P}<0.05$; Fig. 3D-F) at 48 h.

\section{Discussion}

INHBA is a subunit of both activin and inhibin, two closely related glycoproteins with opposing biological effects, which belong to the TGF- $\beta$ superfamily (18-20). The TGF- $\beta$ superfamily comprises a structurally similar, although functionally diverse group of proteins that play important roles in embryonic development as well as in the functions of terminally differentiated tissues. Activins play fundamental roles in cell differentiation and development and are known to induce cellular responses via activin receptors and the SMAD2/3 pathway, while inhibits function to antagonize activins through either competition of receptor binding or $\beta$-glycan.

In the present study, we determined that INHBA is highly expressed in CRC tissues when compared with that in the corresponding normal tissues. In addition, high INHBA expression in $\mathrm{CRC}$ tissues was a predictor of poor prognosis when compared 
Table III. Results of the univariate and multivariate analysis of clinicopathological factors affecting lymph node metastasis.

\begin{tabular}{|c|c|c|c|c|c|c|}
\hline \multirow[b]{2}{*}{ Factors } & \multicolumn{3}{|c|}{ Univariate analysis } & \multicolumn{3}{|c|}{ Multivariate analysis } \\
\hline & RR & $95 \% \mathrm{CI}$ & P-value & $\mathrm{RR}$ & $95 \% \mathrm{CI}$ & P-value \\
\hline Age (years) $(\leq 68 />68)$ & 0.593 & $0.63-3.54$ & 0.324 & - & - & - \\
\hline Gender (Male/female) & 0.571 & $0.172-1.65$ & 0.322 & - & - & - \\
\hline Histological grade (Well, mod/others) & 5.62 & $1.02-28.2$ & $0.0341^{\mathrm{a}}$ & 4.91 & $0.73-98.0$ & 0.16 \\
\hline Depth (T0-T2/T3-T4) & 5.53 & $1.89-18.5$ & $0.0028^{\mathrm{b}}$ & 2.25 & $0.93-5.50$ & 0.072 \\
\hline Lymphatic invasion (Absent/present) & 3.68 & $1.27-12.3$ & $0.0215^{\mathrm{a}}$ & 3.25 & $1.39-7.72$ & $0.0067^{\mathrm{b}}$ \\
\hline Venous invasion (Absent/present) & 2.95 & $0.914-8.91$ & 0.0585 & - & - & - \\
\hline INHBA mRNA expression (Low/high) & 5.93 & $1.81-26.8$ & $0.0074^{\mathrm{b}}$ & 3.95 & $1.71-9.35$ & $0.0014^{\mathrm{b}}$ \\
\hline
\end{tabular}

${ }^{\mathrm{a}} \mathrm{p}<0.05 ;{ }^{\mathrm{b}} \mathrm{p}<0.01$. RR, relative risk; CI, confidence interval; Well, well differentiated adenocarcinoma; mod, moderately differentiated adenocarcinoma; others, poorly differentiated adenocarcinoma and signet cell carcinoma; INHBA, inhibin $\beta \mathrm{A}$.
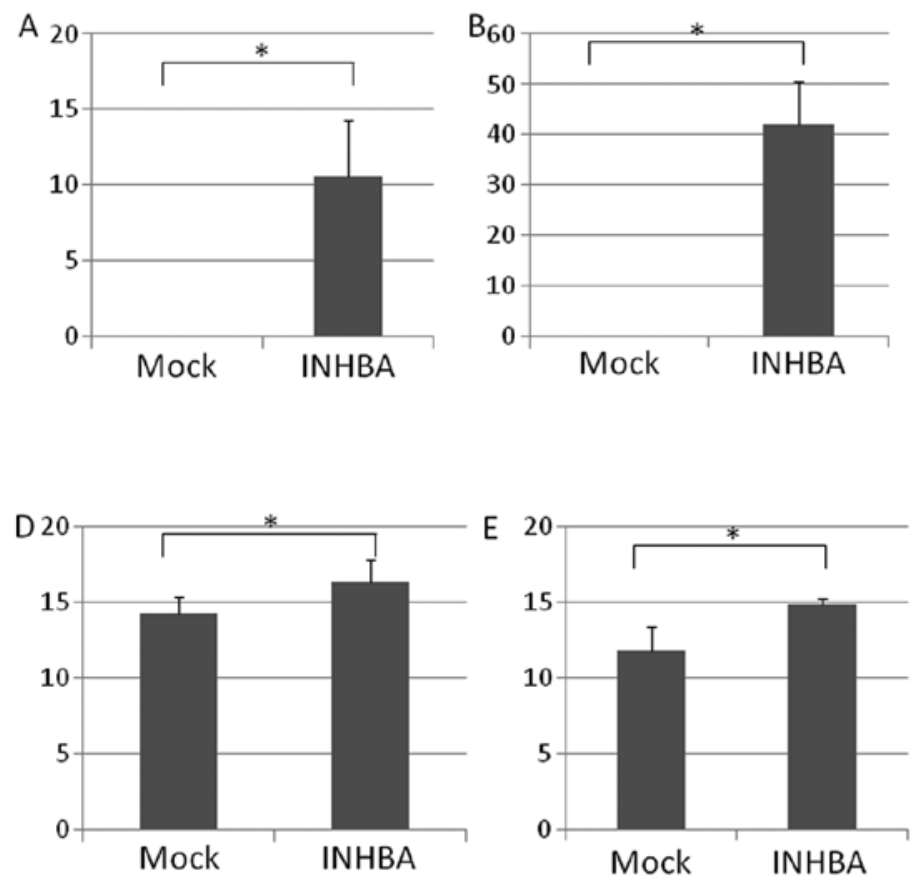
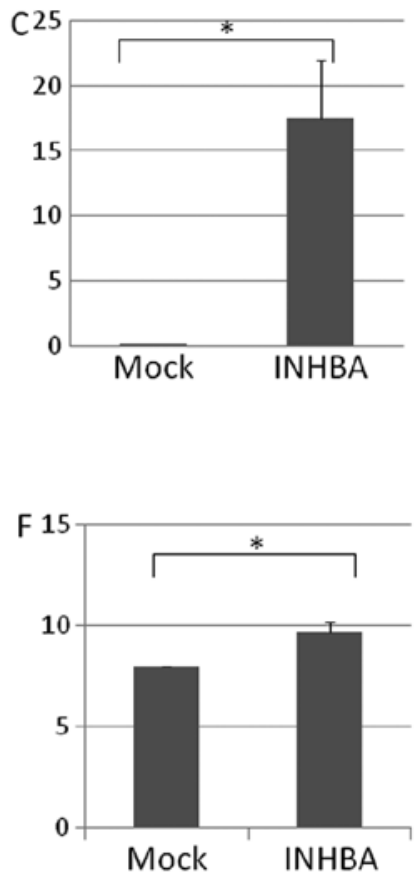

Figure 3. INHBA transfection assessment by plasmids in 3 CRC cell lines. Quantitative real-time RT-PCR was used to confirm INHBA mRNA levels in the cell lines: (A) DLD1, (B) Caco-2 and (C) CCK81. Proliferation assays were performed using (D) DLD1, (E) Caco-2 and (F) CCK81 cells. Significant differences were observed between mock- and INHBA-transfected cells $(\mathrm{n}=3)$. INHBA, inhibin $\beta \mathrm{A}$; CRC, colorectal cancer. ("P<0.05)

with low INHBA expression. Clinicopathological factors related to the INHBA expression status indicated that the high expression group displayed a worse histological grade, higher tumor stage, more lymph node metastasis, poorer lymphatic invasion, greater vascular invasion and more extensive liver metastasis. Therefore, INHBA expression was not an independent prognostic factor but may be strongly related to one of the other prognostic factors of CRC. Thus, this study of the association of high INHBA expression with other prognostic factors indicated that high INHBA expression is an independent prognostic factor for lymph node metastasis. Inclusion in the INHBA mRNA high expression group was an independent predictor of lymph node metastasis, as was lymphatic invasion. The overexpression and knockdown experiments were performed in vitro. These experiments showed that high INHBA expression induced cell growth, whereas low INHBA expression induced an opposite effect.

It is useful to determine the necessity for intensive followup and adjuvant therapy for CRC by predicting recurrence and metastases after curative surgical resection (21-23). In the present study, clinicopathological analysis revealed that patients who had CRCs with high INHBA expression had a poor prognosis for overall survival than those with low expression. The data indicated that INHBA expression is presumably a novel predictor of CRC prognosis. Several adjuvant chemotherapies are helpful at certain disease stages, particularly 
in CRC (23-27). For such cases, an informative prognostic marker, which is independent of the traditional TNM classification, is extremely important and can contribute to diagnosis and treatment. Adjuvant chemotherapy for CRC is necessary for highly suspicious recurrent cases. In such cases, analysis of INHBA expression may be useful for predicting CRC prognosis, and INHBA is also proposed to be a therapeutic target in treatment for patients with poor prognosis.

\section{References}

1. Kohno SI, Luo C, Nawa A, et al: Oncolytic virotherapy with an HSV amplicon vector expressing granulocyte-macrophage colony-stimulating factor using the replication-competent HSV type 1 mutant HF10 as a helper virus. Cancer Gene Ther 14 918-926, 2007

2. Hermsen M, Postma C, Baak J, et al: Colorectal adenoma to carcinoma progression follows multiple pathways of chromosomal instability. Gastroenterology 123: 1109-1119, 2002.

3. Leslie A, Pratt NR, Gillespie K, et al: Mutations of APC, K-ras, and $\mathrm{p} 53$ are associated with specific chromosomal aberrations in colorectal adenocarcinomas. Cancer Res 63: 4656-4661, 2003.

4. Gaddy-Kurten D, Tsuchida K and Vale W: Activins and the receptor serine kinase superfamily. Recent Prog Horm Res 50: 109-129, 1995.

5. Vale W, Rivier C, Hsueh A, et al: Chemical and biological characterization of the inhibin family of protein hormones. Recent Prog Horm Res 44: 1-34, 1988.

6. Lorenzen JR, Channing CP and Schwartz NB: Partial characterization of FSH suppressing activity (folliculostatin) in porcine follicular fluid using the metestrous rat as an in vivo bioassay model. Biol Reprod 19: 635-640, 1978.

7. Asashima M, Ariizumi T and Malacinski GM: In vitro control of organogenesis and body patterning by activin during early amphibian development. Comp Biochem Physiol B Biochem Mol Biol 126: 169-178, 2000.

8. Yoshinaga K, Mimori K, Yamashita K, Utsunomiya T, Inoue H and Mori M: Clinical significance of the expression of activin A in esophageal carcinoma. Int J Oncol 22: 75-80, 2003.

9. Kleeff J, Ishiwata T, Friess H, Büchler MW and Korc M Concomitant over-expression of activin/inhibin $\beta$ subunits and their receptors in human pancreatic cancer. Int $\mathrm{J}$ Cancer 77 : 860-868, 1998

10. Thomas TZ, Wang H, Niclasen $\mathrm{P}$, et al: Expression and localization of activin subunits and follistatins in tissues from men with high grade prostate cancer. J Clin Endocrinol Metab 82: 3851-3858, 1997.

11. Woodruff TK: Role of inhibins and activins in ovarian cancer. Cancer Treat Res 107: 293-302, 2002.

12. Zheng W, Luo MP, Welt C, et al: Imbalanced expression of inhibin and activin subunits in primary epithelial ovarian cancer. Gynecol Oncol 69: 23-31, 1998.
13. Petraglia F, Florio P, Luisi S, et al: Expression and secretion of inhibin and activin in normal and neoplastic uterine tissues. High levels of serum activin A in women with endometrial and cervical carcinoma. J Clin Endocrinol Metab 83: 1194-1200, 1998.

14. Miyoshi $\mathrm{N}$, Ishii $\mathrm{H}$, Sekimoto $\mathrm{M}$, Doki $\mathrm{Y}$ and Mori M: RGS16 is a marker for prognosis in colorectal cancer. Ann Surg Oncol 16: 3507-3514, 2009.

15. Sobin LH and Fleming ID: TNM Classification of Malignant Tumors. 5th edition (1997). Union Internationale Contre le Cancer and the American Joint Committee on Cancer. Cancer 80: 1803-1804, 1997.

16. Mimori K, Mori M, Shiraishi T, et al: Clinical significance of tissue inhibitor of metalloproteinase expression in gastric carcinoma. Br J Cancer 76: 531-536, 1997.

17. Mori M, Staniunas RJ, Barnard GF, et al: The significance of carbonic anhydrase expression in human colorectal cancer. Gastroenterology 105: 820-826, 1993.

18. Burger HG and Igarashi M: Inhibin: definition and nomenclature, including related substances. Endocrinology 122: 1701-1702, 1988.

19. Murata M,Eto Y, Shibai H, Sakai M and Muramatsu M: Erythroid differentiation factor is encoded by the same mRNA as that of the inhibin $\beta_{\mathrm{A}}$ chain. Proc Natl Acad Sci USA 85: 2434-2438, 1988.

20. Brown CW, Houston-Hawkins DE, Woodruff TK and Matzuk MM: Insertion of Inhbb into the Inhba locus rescues the Inhba-null phenotype and reveals new activin functions. Nat Genet 25: 453-457, 2000.

21. Wolpin BM and Mayer RJ: Systemic treatment of colorectal cancer. Gastroenterology 134: 1296-1310, 2008.

22. Kornmann M, Formentini A, Ette C, et al: Prognostic factors influencing the survival of patients with colon cancer receiving adjuvant 5-FU treatment. Eur J Surg Oncol 34: 1316-1321, 2008.

23. Bathe OF, Dowden S, Sutherland F, et al: Phase II study of neoadjuvant 5-FU + leucovorin + CPT-11 in patients with resectable liver metastases from colorectal adenocarcinoma. BMC Cancer 4: 32, 2004.

24. Lacy AM, Garcia-Valdecasas JC, Delgado S, Castells A, Taurá P, Piqué JM and Visa J: Laparoscopy-assisted colectomy versus open colectomy for treatment of non-metastatic colon cancer: a randomised trial. Lancet 359: 2224-2229, 2002.

25. Weeks JC, Nelson H, Gelber S, et al: Short-term quality-of-life outcomes following laparoscopic-assisted colectomy vs open colectomy for colon cancer: a randomized trial. JAMA 287: 321-328, 2002.

26. Clinical Outcomes of Surgical Therapy Study Group: A comparison of laparoscopically assisted and open colectomy for colon cancer. N Engl J Med 350: 2050-2059, 2004.

27. Jayne DG, Guillou PJ, Thorpe H, et al: Randomized trial of laparoscopic-assisted resection of colorectal carcinoma: 3-year results of the UK MRC CLASICC Trial Group. J Clin Oncol 25: 3061-3068, 2007. 